\section{Cellular Physiology and Biochemistry}

\title{
Blocking Type I Interferon (IFN) Signaling Impairs Antigen Responsiveness of Circulating Lymphocytes and Alters Their Homing to Lymphoid Organs: Protective Role of Type I IFN
}

\author{
Gamal Badr ${ }^{1,2,3}$, Hanan Waly ${ }^{1}$, Heba M. Saad Eldien ${ }^{4}$, Hanem Abdel- \\ Tawab $^{1}$, Khadega Hassan ${ }^{1}$, Ibrahim M. Alhazza ${ }^{2,3}$, Hossam Ebaid ${ }^{3}$ \\ and Saleh H. Alwasel $\mathrm{l}^{2,3}$ \\ ${ }^{1}$ Zoology Department, Faculty of Science, Assiut University, ${ }^{2}$ Fetal Programming of Diseases Research \\ Chair, College of Science, King Saud University, ${ }^{3}$ Zoology Department, Faculty of Science, King Saud \\ University, ${ }^{4}$ Histology Department, Faculty of Medicine, Assiut University
}

\section{Key Words}

Anti-IFNR1 • Apoptosis • B Lymphocytes • Lymphoid Tissues • Proliferation • T Lymphocytes • Type I IFN

\begin{abstract}
Background: We recently demonstrated that type I Interferon (IFN) rescues in vitro, human Blymphocytes from apoptosis via PI3K /Akt, Rho-A, $\mathrm{NF} \kappa \mathrm{B}$ and $\mathrm{Bcl}-2 / \mathrm{BclXL}$. In the present study we extended our work to clarify, in vivo, the role of type I IFN signalling on the circulating and lymphoid organs homing lymphocytes. Methodology: Two groups of mice 13 in each were set: type I IFN signalling blocked mice injected with anti-IFNAR1 antagonist antibody (10 $\mathrm{mg} / \mathrm{kg}$ body weight) once/day for up to 20 days, and control group were injected with vehicle alone. Results: Flow cytometry analysis to monitor the blood lymphocyte phenotype and proliferation have shown a significant decrease in CD45R/CD220 ${ }^{+}$B cells, $\mathrm{CD}^{+}$and $\mathrm{CD}^{+} \mathrm{T}$ cells in treated animals. Furthermore, the proliferative capacities of these lymphocyte subsets were significantly decreased in treated animals compared to those of control mice. Marked reduction in the plasma levels of IL-2 and IL-7 (cytokines
\end{abstract}

\section{KARGER}

Fax +4161306 1234

E-Mail karger@karger.ch

www.karger.com
(C) 2010 S. Karger AG, Basel

$1015-8987 / 10 / 0266-1029 \$ 26.00 / 0$

Accessible online at: www.karger.com/cpb important for the development of $\mathrm{T}$ and $\mathrm{B}$ cells) but not of IL-6 or IL-10 was observed in treated mice and this may a cause for emergence decrease in $B$ and $T$ cell numbers. Immunohistochemical studies have further shown a marked reduction in the numbers of CD20 $0^{+}$B cells in spleen and Peyer's patches and $\mathrm{CD}^{+} \mathrm{T}$ cells in thymus of treated animals. Moreover, electron microscopy examinations have revealed a loss of lymphocytes with characteristic features of apoptosis. Conclusion: Our data confirmed that the in vivo inhibition of type I IFN signaling induce decrease in the numbers and defective functions of circulating and lymphoid organs homing lymphocytes providing a strong evidence for the protective effects of type 1 IFNs (IFN- $\alpha / \beta)$ on B and T lymphocytes.

Copyright $\subset 2010$ S. Karger AG, Basel

\section{Introduction}

It is accepted that type I interferons (IFNs, i.e. IFN- $\alpha / \beta$ ) influence the proliferation, differentiation, and function of various types of cells in the immune system 
[1]. Type I IFNs exert their actions through cognate cell surface receptor that is largely species specific and appears to be a common receptor consisting of two subunits, IFN-alpha receptor 1 (IFNAR-1) and IFN-alpha receptor2 (IFNAR-2) [2, 3].

There is a great deal of evidence showing that IFNAR2 subunit is the major ligand-binding component whereas IFNAR1 is the signaling subunit of type 1 IFN receptor $[4,5]$. Type I IFNs bind IFNAR receptors and activate Jak kinases and Stat transcription factors to stimulate the transcription of genes downstream from IFNstimulated response elements [6]. Numerous studies confirmed that mice lacking IFN- $\alpha / \beta$ receptor (IFN- $\alpha / \beta$ $\mathrm{R}^{--}$mice) are highly sensitive to a number of viral infections $[7,8]$. Infection of mice lacking the functional type I IFN receptor (IFNAR ${ }^{-/}$) with mouse hepatitis virus (MHV) resulted in increased viral replication and extended tissue tropism [9]. Moreover, blocking IFN- $\alpha / \beta$ activity in mice leads to a dramatically increased sensitivity to many viruses. Genetically targeted knockout mice lacking the $\beta$ subunit of the IFN- $\alpha / \beta$ receptor (IFNAR ${ }^{-/}$) are unable to establish an antiviral state and, as a consequence, are highly susceptible to many viral infections, despite the presence of an otherwise intact immune system [10, 11]. Recently, Deonarain et al. [12] found that the deletion of the IFNAR gene in the IFNAR1 mice resulted in the disruption of IFN- $\alpha / \beta$-induced signaling, which is an important determinant of the tissue tropism and pathogenicity of poliovirus. Similarly, it has been reported that IFN- $\alpha / \beta$ plays an important role in the pathogenicity and tissue damage of some viruses. The lack of an IFN system allows the virus to replicate more efficiently. IFNAR ${ }^{-/}$knockout mice have been used as a laboratory animal model to study the immune response and pathogenicity of coronaviruses, vaccinia virus Ankara strain (MVA), measles virus, Rift valley fever virus and West Nile virus, but not to follow up the immune system compartments such as lymphoid organs architectures and lymphocyte functions [13-15].

We have recently demonstrated that IFN- $\alpha /$ and $-\beta$ rescues human B-lymphocytes from apoptosis through $\mathrm{PI} 3 \mathrm{~K} \delta$ /Akt, Rho-A, NFKB and $\mathrm{Bcl}-2 / \mathrm{Bcl}_{\mathrm{xL}}$ activation [16]. Therefore, in the present study we further investigated the relation between type I IFN signaling and survival/cell death and function of circulating as well as lymphoid tissues homing lymphocytes using animal model lacking type I IFN signalling induced by anti-IFNR1 blocking antibody.

\section{Materials and Methods}

\section{Animals}

Laboratory bred Swiss albino mice of 6-8 weeks of age, weighing 23-30 g were obtained from Central Animal House, Faculty of Medicine, Assiut University. All animal procedures were in accordance with the standards set forth in guidelines for the care and use of experimental animals by Committee for Purpose of Supervision of Experiments on Animals (CPCSEA) and according to National Institute of Health (NIH) protocol Animals were allowed to acclimatize for 2 weeks before the experiment and were housed in metal cages inside a well-ventilated room. They were maintained under standard laboratory conditions of temperature $25^{\circ} \mathrm{C}$, relative humidity $60-70 \%$ and 12 hour light/dark cycle and were fed a standard commercial pellet diet and water. A total number of twenty six adult male mice were equally divided into two groups: the first group was kept as control and received vehicle. The second group was injected with anti-IFNAR1 antagonist $(10 \mathrm{mg} / \mathrm{kg}$ body weight once/day) for up to 20 days according to NIH protocol to block type I IFN receptor signalling.

\section{Blood and tissues samples}

At the end of this experiment, mice were anesthetized with pentobarbital $(60 \mathrm{mg} / \mathrm{kg}$ body weight), abdominal cavity was opened, and whole blood was drawn from the abdominal aorta. Plasma was obtained by low-speed centrifugation (1000 $\mathrm{Xg}$ for $20 \mathrm{~min}$ ) and immediately stored at $-80^{\circ} \mathrm{C}$ for later cytokine profile analysis. While peripheral blood mononuclear cells (PBMCs) were isolated by ficoll gradient method. Specimens from thymus, spleen, Peyer's patches and ileum were obtained and processed for histological, immunohistochemical and untrastructural examinations.

\section{Flow Cytometry Assay}

The flow cytometry assay was used to monitor B- and T lymphocyte populations in the blood of control and treated mice and also to measure their proliferation capacity using fluorescence activated cell sorting (FACS) and FACSCalibur flow cytometry instruments from BD Bioscience. In brief, Peripheral Blood Mononuclear Cells (PBMCs) were isolated using Ficoll gradient method. Freshly isolated cells were incubated for 4 hours in R-10 culture media (RPMI $1640+10 \%$ FBS $+1 \%$ antibiotic) before staining as recommended by NIH protocol PBMCs were harvested and washed with 1X PBS (Gibco BRL). The cells were blocked with human serum $\mathrm{AB}$ for $15 \mathrm{~min}$ at $4^{\circ} \mathrm{C}$ to inhibit nonspecific staining, and then stained with fluorescently labeled monoclonal antibodies (mAbs) to the mouse antigens of interest at optimal concentrations for an additional $30 \mathrm{~min}$ at $4^{\circ} \mathrm{C}$. Abs (BD Biosciences, San Jose, CA) were directly labeled with the following fluorescent tags: fluorescein isothiocyanate (FITC) or phycoerythrin (PE) for CD4 [H129.19 and rat (Lou/WS1) IgG2a, א], CD8 [53-6.7 and rat $\mathrm{IgG} 2 \mathrm{a}, \kappa]$ and CD45R/B220 [RA3-6B2 and rat IgG2a, $\kappa$ ]. In the phenotyping experiments we used CD4-FITC as a specific 
marker for T-helper lymphocytes and NK-T lymphocytes, CD8$\mathrm{PE}$ as a specific marker for cytolytic T lymphocytes and dendritic cells and CD45R/ B220-FITC as a specific marker for pan $\mathrm{B}$ lymphocytes and abnormal T cells. Appropriate isotype controls were always included. After centrifugation, the cells were fixed with fixation buffer (PBS $+2 \%$ formalin), and 25,000 viable cells per treatment (as determined by light scatter profiles) were analyzed via a BD FACSCalibur ${ }^{\mathrm{TM}}$ flow cytometer and CellQuest or FlowJo software (BD Biosciences).

\section{CFSE-Labeled Cell Proliferation Assay}

To measure the proliferation and differentiation of lymphocytes, we performed a carboxy fluorescein diacetate succinimidyl ester (CFSE) assay. Normally, after cell division, CFSE labeling is distributed equally between daughter cells, each of which is, therefore, half as fluorescent as the parent. For this assay, PBMCs were re-suspended at $20 \times 106 / \mathrm{ml} 1 \mathrm{X}$ PBS and were then stained with $0.63 \mu \mathrm{M}$ CFSE (Molecular Probes, Eugene, OR) for $8 \mathrm{~min}$ at room temperature. The reaction was stopped with FBS; cells were washed three times in $1 \mathrm{X} \mathrm{PBS}$ and then re-suspended at $2 \times 106$ cells $/ \mathrm{ml}$ in prewarmed R-10 medium. CFSE-labeled B cell were stimulated for 6 days with or without Concanavalin A (ConA) (final concentration, 5 $\mu \mathrm{g} / \mathrm{ml}$ ) or phorbol myristate acetate (PMA; $10 \mathrm{ng} / \mathrm{ml}$; SigmaAldrich Chemie, Vienna, Austria) plus ionomycin calcium (500 $\mathrm{ng} / \mathrm{ml}$; Sigma-Aldrich) at $37^{\circ} \mathrm{C}$ and $5 \% \mathrm{CO} 2$. Similarly, CFSElabeled $\mathrm{T}$ cells were stimulated with anti-CD3/CD28. On day 6 , cells were washed in PBS and were stained with surface antigens anti-CD3-PE, CD45A/CD220-PE [RA3-6B2 and rat IgG2a, $\mathrm{K}$ ] or isotype control (BD biosciences). Data were collected for 50,000 cells and analyzed via a BD FACSCalibur ${ }^{\mathrm{TM}}$ flow cytometer and FlowJo software (BD Biosciences). Proliferating lymphocyte subsets were distinguished by low CFSE.

\section{Determination of plasma cytokine levels}

Plasma cytokine profile (IL-2, IL-6, IL-7, IL-10 and TNF- $\alpha$ ) levels were determined by ELISA using mice Bio-Plex cytokine assay kit (Bio-Rad, Hercules, CA), according to the manufacturer's instructions.

\section{Immunohistochemical (IHC) study}

Tissues samples were fixed in $10 \%$ neutral buffered formalin Paraffin sections were cleared in xylene, rehydrated in graded ethanol $(100 \%-70 \%)$, immersed in water for 5 to 10 minutes, and incubated in $0.3 \% \mathrm{H} 2 \mathrm{O} 2$ in $70 \%$ methanol for 20 minutes to inhibit endogenous peroxidase activity. The specimens were then rinsed three times for 5 minutes in PBS, and epitopes were unmasked by boiling in citrate buffer ( $\mathrm{pH}$ 6.0) for 10 to 15 minutes, when necessary. After rinsing in PBS, the sections were blocked for 30 to 60 minutes in 3\% BSA in PBS or in $5 \%$ goat or rabbit serum in PBS, and then were incubated with primary antibodies (anti-CD3; pan T cells and anti-CD20; pan B cells) in $0.1 \%$ BSA in PBS overnight at $4{ }^{\circ} \mathrm{C}$ in a humidified chamber. Samples were then rinsed in PBS and incubated with $7.5 \mathrm{~g} / \mathrm{mL}$ of biotinylated secondary antibody in $0.1 \% \mathrm{BSA}$ in PBS for 1 hour at room temperature, followed by avidin biotin amplification (ABC Elite) for 30 minutes, and were developed with 3,3-diaminobenzidine peroxidase substrate. Sections were counterstained with Mayer haematoxylin for 2 to 5 minutes and mounted. Negative controls were set by substituting the primary antibody with PBS [17]. The intensity of staining in $\mathrm{B}$ and $\mathrm{T}$ cells of the tissue sections was assessed using the histological score (HSCORE) as previously described [18, 19]. The HSCORE was calculated using the following equation: HSCORE $=\Sigma \mathrm{Pi}(\mathrm{i}+1)$, where $\mathrm{i}$ is the intensity of staining $(1=$ weak, $2=$ moderate and $3=$ strong) and $\mathrm{Pi}$ is the percentage of stained $\mathrm{B}$ and $\mathrm{T}$ cells for each intensity $(0-100 \%)$. The Histological evaluation of tissue sections were scored by two independent investigators in a blinded fashion without the knowledge of sample identifiers, using a light microscope (Olympus, $\mathrm{CH}-2$; Hitech Instruments, Inc., Edgemont, PA), and the average HSCORE was documented. This semiquantitative analysis has been shown to have a low intra- and inter observer variation [18].

\section{Electron microscopic study}

For the electron microscopic examination, small pieces $(1 \times 1 \mathrm{~mm})$ of Thymus, spleen and Peyer's patches of both treated and control mice were quickly removed, and fixed in $5 \%$ cold buffer glutaraldehyde for one week. The specimens were then washed in phosphate buffer ( $\mathrm{pH}$ 7.2) four changes of 15 minutes each with slow shaking and post fixed in $1 \%$ osmium tetroxide for $2 \mathrm{hrs}$. They were washed again with phosphate buffer then dehydrated using ascending grades of alcohol. 50\% for 30 minutes, at $70 \%$ overnight, at $95 \%$ for 30 minutes and finally at $100 \%, 3$ changes of 30 minutes each. Samples were embedded in propylene oxide for 30 minutes to remove remnants of alcohol. After that samples were embedded in propylene oxide plus Epon $812(1: 1, \mathrm{v} / \mathrm{v})$ for 30 minutes and finally they were embedded in Epon 812 for 4 hrs. Samples were finally embedded into capsules containing the embedding mixture and the tissue blocks were polymerized in an oven for 2 days at $60^{\circ} \mathrm{C}$. Semithin sections of $0.5 \mathrm{ì} \mathrm{m}$ thickness were prepared using LKB ultramicrotome and then stained with toluidine blue. Semithin sections were examined for localization of the desired tissues and accordingly ultrathin sections were prepared. Sections were stained with uranyl acetate and lead citrate and examined under transmission electron microscope (Jeol, 100 CXII) operated at $80 \mathrm{KV}$, Electron Microscopic Center, Assiut University. Electron micrographs were taken for selected semithin regions, reconstructed and processed using Photoshop computer program to study spleen, peyer's patches and thymus. The results were presented as micrographs and discussed in view of a valuable literature [20]. For the histological examination, the cut sections were stained with Hematoxylin-Eosin (H\&E) according to [21].

\section{Statistical analysis}

Differences between groups were assessed using analysis of variance (ANOVA) and SPSS software version 16 . 


\section{Results}

In vivo blocking Type I IFN signaling induces reduction in the numbers of blood $B$ - and $T$ lymphocytes

To define the specific lymphocyte populations in the blood of control and anti-IFNAR-treated mice, PBMCs (5 x 105) were stained with anti- CD45R/B220 (pan B cells), anti-CD4, anti-CD8 or isotype control. Twenty five thousand viable cells were analyzed by flow cytometry via the correlated measurements of forward-angle light scatter plotted against right-angle light scatter. In a cytogram, three main clusters could be seen that related to the three major cell types: lymphocytes, monocytes, and polymorphonuclear granulocytes. Gating on lymphocyte population, we found in one representative experiment that the number of B lymphocytes was markedly reduced from $49 \%$ in control animal to $37 \%$ in treated animal (Fig. 1 A). Similarly, the numbers of CD4 ${ }^{+}$ helper $\mathrm{T}$ lymphocytes and $\mathrm{CD} 8^{+}$cytotoxic $\mathrm{T}$ lymphocytes were obviously reduced from $57 \%$ and $11 \%$ in control animal to $39 \%$ and $4 \%$ in treated animal, respectively (Fig. $1 \mathrm{~B}$ and $\mathrm{C}$ ). From nine separate experiments, a marked reduction in the numbers of $B$ and $T$ lymphocytes were detected in anti-IFNAR-treated mice compared to control mice. The number of B lymphocytes was significantly $(\mathrm{P}<0.05)$ reduced from $46.8 \pm 4.6$ in control mice to $34.6 \pm 4.1$ in type I IFN signaling-blocked mice (Fig. 1D). Moreover, the numbers of CD4+ and CD $8 \pm \mathrm{T}$ cell populations were significantly $(\mathrm{P}<0.05)$ reduced from 55.9 \pm 5.2 and $9.6 \pm 2.6$ in control mice to $37.9 \pm 2.6$ and 4.9 \pm 1.8 in type I IFN signaling-blocked mice, respectively. Although we gated on the same number of PBMCs, a marked elevation of necrotic cell population was found within the lymphocyte population of treated mice (data not shown).

Mitogen-stimulated lymphocytes from treated mice exhibit diminished proliferative capacity

To confirm whether ECK enhances the differentiation and proliferation of $\mathrm{T}$ and $\mathrm{B}$ cells, PBMCs were labeled with CFSE, stimulated with mitogen or without stimulation and cultured for 6 days. On day 6 , cells were counted using trypan blue exclusion test before staining with $\mathrm{mAbs}$ to defined lymphocyte populations. A marked reduction was observed in the cell recovery number in anti-IFNAR-treated mice (data not shown). Using flow cytometry, we measured the progressive decrease in intensity of the CFSE dye in each succeeding T- and Bcell generation. Normally, CFSE-FITC is transferred from

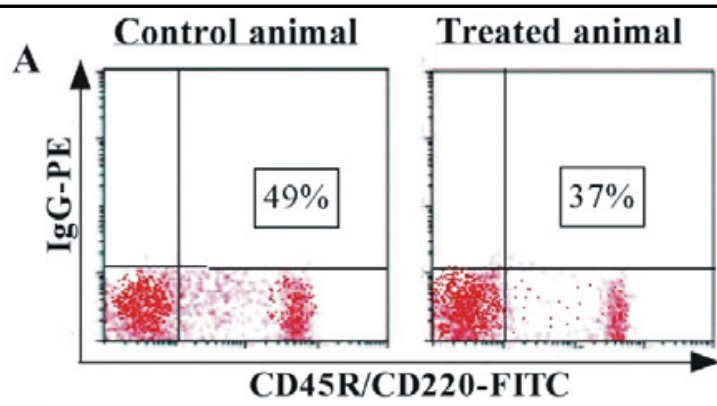

B

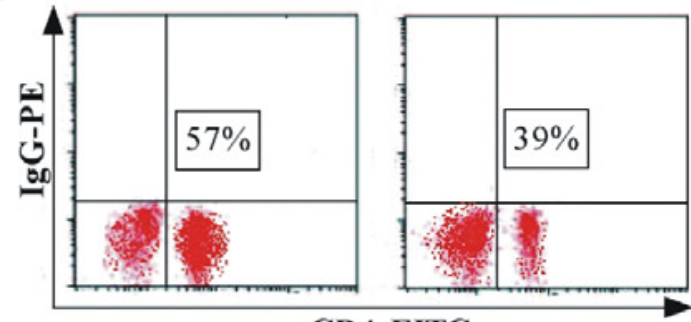

C

CD4-FITC

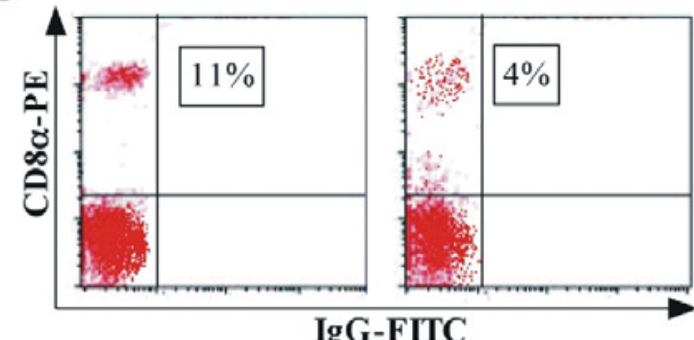

D

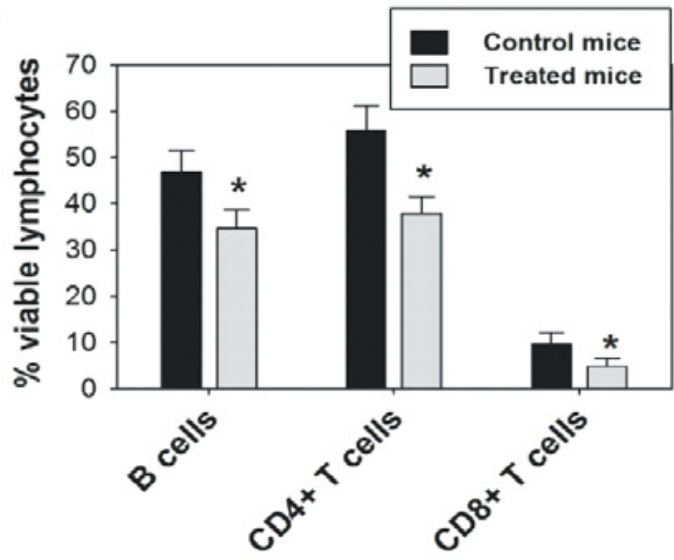

Fig. 1. Phenotypic analysis of blood lymphocyte populations in animal groups Freshly isolated PBMCs were cultured in R10 media at $37 \mathrm{C}$ for 4 hours before staining with antibodies. Gating 25000 events per treatment, the expression level of each cell type was measured via FACS analysis using anti-CD45R/ B220 for B cells (A), anti-CD4 for helper T cells (B) and antiCD8 for cytotoxic T cells (C). Representative dot-plots of B cells, CD4 and CD8 T cells from one representative experiment are shown. (D) The experiment was repeated with samples from 9 different mice from control group (closed black bars) and treated group (closed gray bars), and results are expressed as the mean percentage of viable lymphocyte population plus or minus $\mathrm{SD}(\mathrm{n}=9), \mathrm{P}<0.05$.

Badr/Waly/Saad Eldien/Abdel-Tawab/Hassan/Alhazza/Ebaid/Alwasel 
Fig. 2. Reduced lymphocyte proliferation in anti-IFNAR1treated mice Using anti- CD45R/B220 Ab, the proliferative capacity of $\mathrm{B}$ cells from isolated $\mathrm{PBMCs}$ was measured by CFSE dilution assay in response to Con-A or PMA+ Ionomycin following 6 days of stimulation. Plots are gated on viable CD45R/ $\mathrm{B} 220-\mathrm{PE}^{+} \mathrm{B}$ cells and percentage of $\mathrm{B}$ cell proliferation is represented by dot-plots (left column) or histograms (right column). Cells inside the quadrants (in the left column) or right histograms (in the right column) represent the percentage of proliferating cells (CFSE-lo) within the B cell population. Undivided cells are represented by CFSE-high population or histogram within the $\mathrm{B}$ cell population. One representative experiment is shown where unstimulated $(A \& C)$ and mitogen-stimulated $B$ cells (B\&D) from control and treated mice are presented. (E) The experiment was repeated with samples from 8 different mice from control group (closed black bars) and treated group (closed gray bars), and results are expressed as the mean \pm SD percentages of CFSE negative cells ( $\%$ of proliferation) $(n=8)$, $\mathrm{P}<0.05$.

parent cells to daughter cells. As shown in Fig. 2, the proliferation of CFSE-labeled CD45R/B220 $0^{+}$pan B cells was expressed in dot plot (left column) and histograms representing the cell division (right column). Notably, the percentage of CFSE-labeled unstimulated CD45R/B220 cells was $1 \%$ (Fig. $2 \mathrm{~A}$ ) and increased to $70 \%$ in mitogen-stimulated B cells (Fig. 2 B) in control animal. While, blocking type I IFN signaling results in obvious reduction in the proliferation of B cells from $0.4 \%$ in unstimulated (Fig. 2 C) to $45 \%$ in mitogen-stimulated cells (Fig. 2 D) respectively. Similarly, the proliferation of CFSE-labeled $\mathrm{CD}^{+}$pan $\mathrm{T}$ cells was also assessed (data not shown). From 8 separate experiments as shown in Fig. 2 E, we found a marked reduction in the specific proliferation of both $\mathrm{B}$ and $\mathrm{T}$ lymphocytes in treated mice. The specific proliferation was calculated by subtraction the percentage of proliferation in mitogen-stimulated cells minus the percentage of proliferation in non-stimulated cells. The specific proliferation of $\mathrm{B}$ cells was significantly $(\mathrm{P}<0.05)$ decreased from $65.6 \pm 4.8$ in control mice to $44.3 \pm 3.66$ in type I IFN signaling-blocked mice, likewise the specific proliferation of $\mathrm{T}$ cells was significantly $(\mathrm{P}<0.05)$ decreased from $53 \pm 7.1$ in control mice to $37 \pm 5.4$ in type I IFN signaling-blocked mice.

\section{Plasma cytokine profile of anti-IFNAR1-treated} mice

Maintaining mature normal functional lymphocytes requires secretion of/interaction with cytokines. We there-

Type I IFN is Required for Functional Lymphocytes
A

Control animal: unstimulated PBMCs
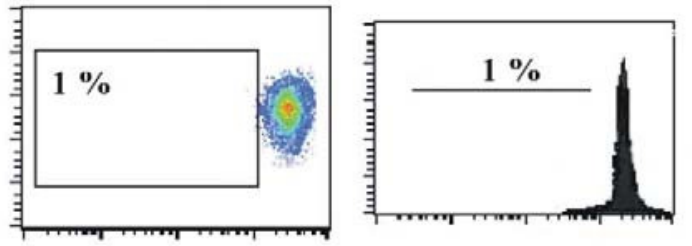

B

Control animal: stimulated PBMCs
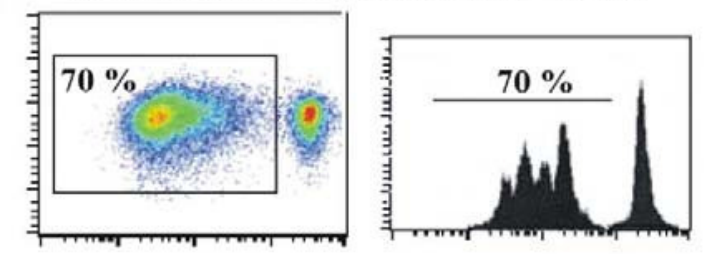

C

Treated animal: unstimulated PBMCs
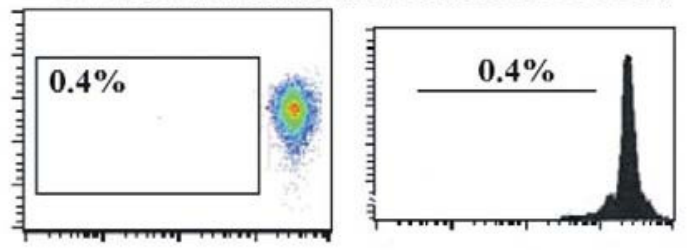

D

Treated animal: stimulated PBMCs

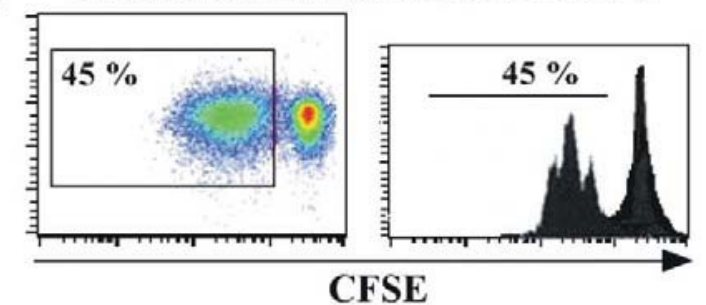

E

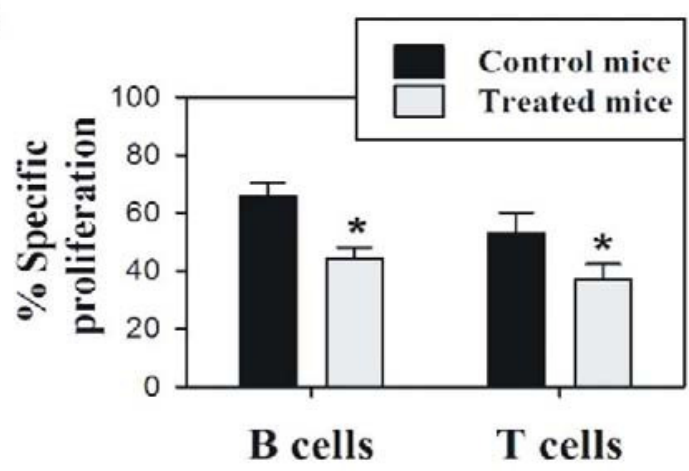

fore measured the plasma levels of certain cytokines that maintain functional lymphocytes such as IL-2, IL-4, IL7, or affect their functions such as IL-6, IL-10 and TNF$\alpha$ using ELISA assay. From nine different experiments we found that the plasma levels of IL-2 and IL-7 were significantly decreased from $25 \pm 3.7$ and $23.8 \pm 4.9$ in control mice to $11 \pm 3.9$ and $9.3 \pm 3.3$, respectively in anti-IFNAR1-treated mice (Fig. 3). While the level of IL-4 was decreased but not significantly from $36.3 \pm 7$ in

Cell Physiol Biochem 2010;26:1029-1040 1033 


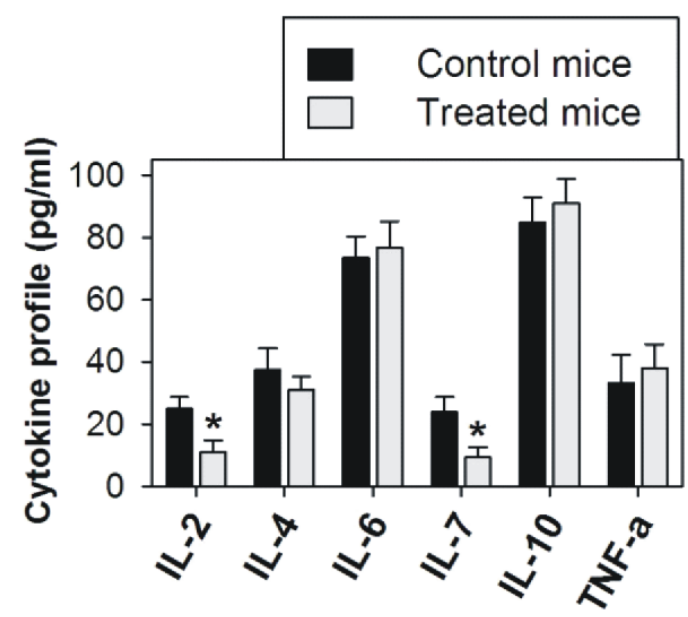

Fig. 3. Plasma cytokine profile in the control and anti-IFNAR1treated mice. Plasma cytokine levels of IL-2, IL-4, IL-6, IL-7, IL10 and TNF- $\alpha$ were measured in nine different animals from control group (closed black bars) and nine animals from treated group (closed gray bars) using Bio-Plex Cytokine assay kit. Data are expressed as the mean $\pm \mathrm{SE}$ of cytokine level $(\mathrm{pg} / \mathrm{ml})$.

control mice to $32.4 \pm 4.3$ in anti-IFNAR1-treated mice. Otherwise, the levels of IL- 6 , IL-10 and TNF- $\alpha$ were slightly but not significantly increased from $73.4 \pm 6.9$, $84.9 \pm 8$ and $33.2 \pm 9$ to $76.7 \pm 8.5,90 \pm 7.8$ and $37.5 \pm$ 7.6 , respectively in anti-IFNAR1-treated mice.

\section{Immunohistochemical and ultrastructure exami- nations}

Splenic lymphocytes. To ensure whether decreased $\mathrm{B}$ and $\mathrm{T}$ cell numbers in the periphery as shown previously in this work is due to an increase in lymphocyte infiltration in the lymphoid organs or is an outcome of a defect in lymphocyte development and homing in the lymphoid organs, tissue sections from different lymphoid organs were processed and stained with anti-CD3 and antiCD20. Firstly, naked eye examination revealed that splenomegaly was a clear feature in the most samples taken from anti-IFNAR1-treated mice compared to that of the control animals (Fig. 4 A). Light microscopic examination showed dilated blood sinusoids and congested by RBCs and scattered lymphocytes, in the treated mice (Fig. 4 B). CD20 $0^{+}$B cells were distinguished with detectable colour in the splenic white and red pulps of control (Fig. 4 C\&D) and an obvious decrease in B cells

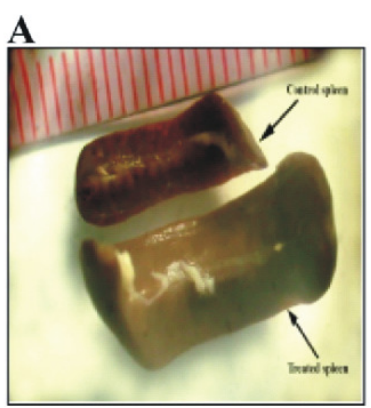

C
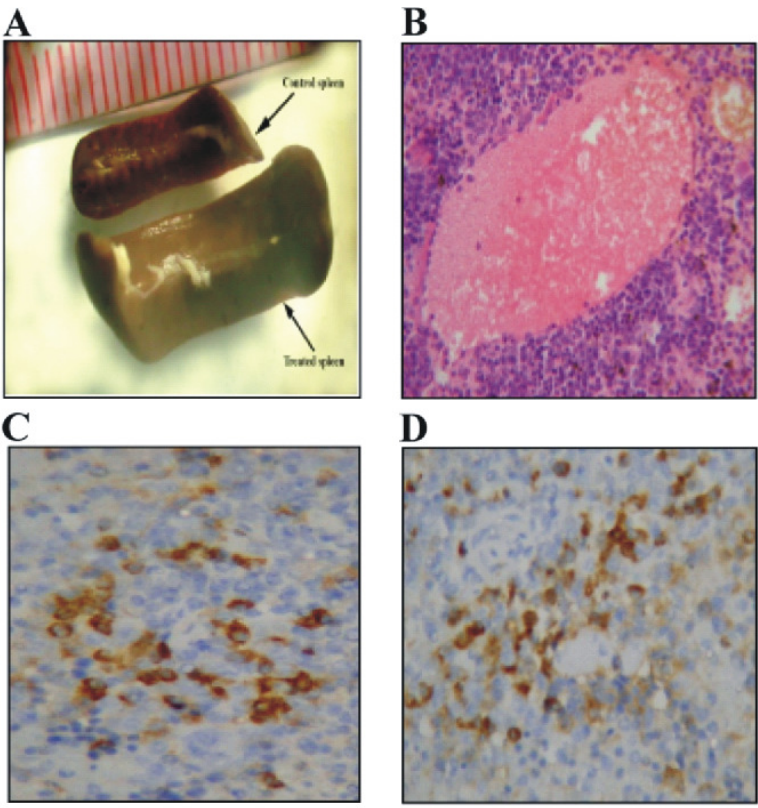

E

D
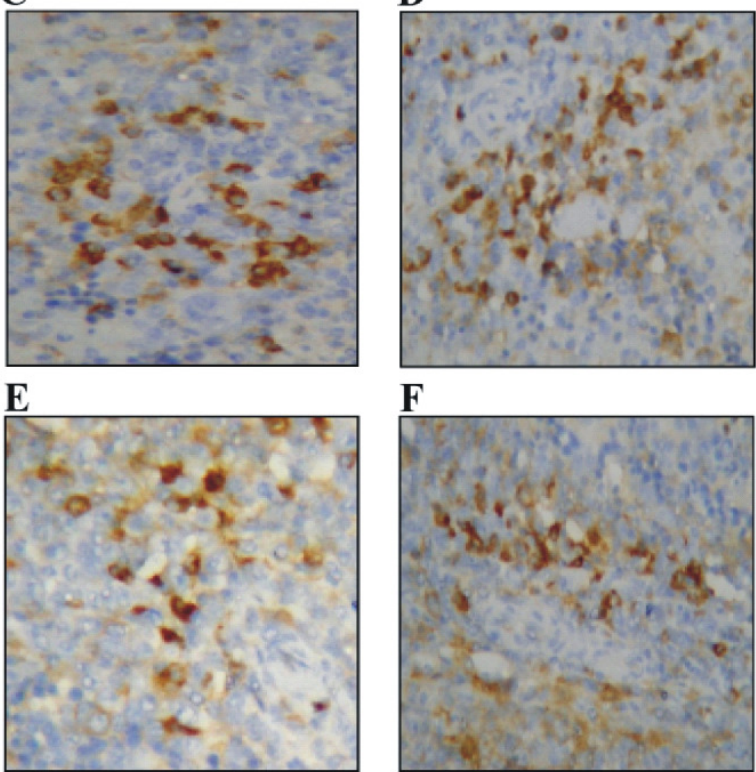

G
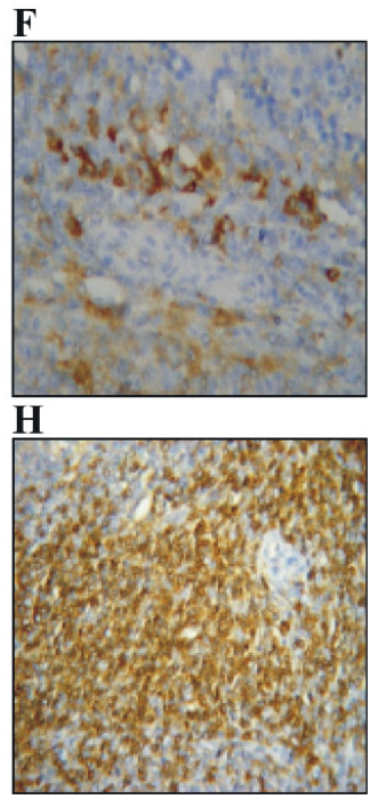

Fig. 4. Histological examination showing reduced B cell number and increased infiltration of $\mathrm{T}$ cells in the spleen of anti-IFNAR1-treated mice. An enlargement occurs in the spleen of treated mice in comparison to that of the control (A). Sections were taken from control (C-E-G) and anti-IFNAR1-treated (B-D-F-H) mice. Representative histology sections (original magnification, $\times 400$ ) were analyzed by hematoxylin/eosin staining (B) and immunofluorescent staining $(\mathrm{C}-\mathrm{H})$ with anti-CD20 (C-F) or CD3 (G-H).

was observed in treated animals (Fig. 4 E\&F). In contrast, $\mathrm{CD}^{+} \mathrm{T}$ cells were markedly increased in the periarterial lymphatic sheath and marginal zone of the white

Badr/Waly/Saad Eldien/Abdel-Tawab/Hassan/Alhazza/Ebaid/Alwasel 


\begin{tabular}{lcccccc}
\hline & \multicolumn{3}{c}{ B cells } & \multicolumn{3}{c}{ T cells } \\
Lymphoid Tissues & $\begin{array}{c}\text { Control } \\
\text { mice }\end{array}$ & $\begin{array}{c}\text { Anti-IFNAR1 - P value } \\
\text { treated mice }\end{array}$ & $\begin{array}{c}\text { Control } \\
\text { mice }\end{array}$ & $\begin{array}{c}\text { Anti-IFNAR1 - } \\
\text { treated mice }\end{array}$ & P value \\
\hline Spleen (White pulp) & 2.4 & 1.55 & 0.04 & 1.93 & 3 & 0.033 \\
Spleen (Red pulp) & 2.5 & 1.8 & 0.043 & 1.98 & 3 & 0.029 \\
Thymus & ND & ND & ------ & 3 & 1.56 & 0.0199 \\
Peyers patches & 2.9 & 1.3 & 0.021 & 1.88 & 3 & 0.037 \\
\hline
\end{tabular}

Table 1. Immunostaining of lymphoid tissues using anti-CD3 (pan T cell) and anti-CD20 (pan B cells). There was a significant decrease in CD20+ B cell number in the spleen and Peyer's patches of anti-IFNAR1treated mice compared to control mice. Likewise, significant decrease in $\mathrm{CD}^{+} \mathrm{T}$ cell number was observed in the thymus gland. Otherwise, enlarged spleen and Peyer's patched was clearly observed in anti-IFNAR1treated mice and this enlargement was due to significant increase in $\mathrm{CD}^{+} \mathrm{T}$ cell numbers in the spleen and Peyer's patches tissues. The statistical method used was Kruskal-Wallis.

Fig. 5. Electron microscopic examination showing apoptotic/mitotic properties of the splenic cells in the antiIFNAR1-treated mice. Thin sections from the spleen tissue of the control (A-B-C) and treated (D-E-F-G-H-I-J) mice were examined with electron microscope.

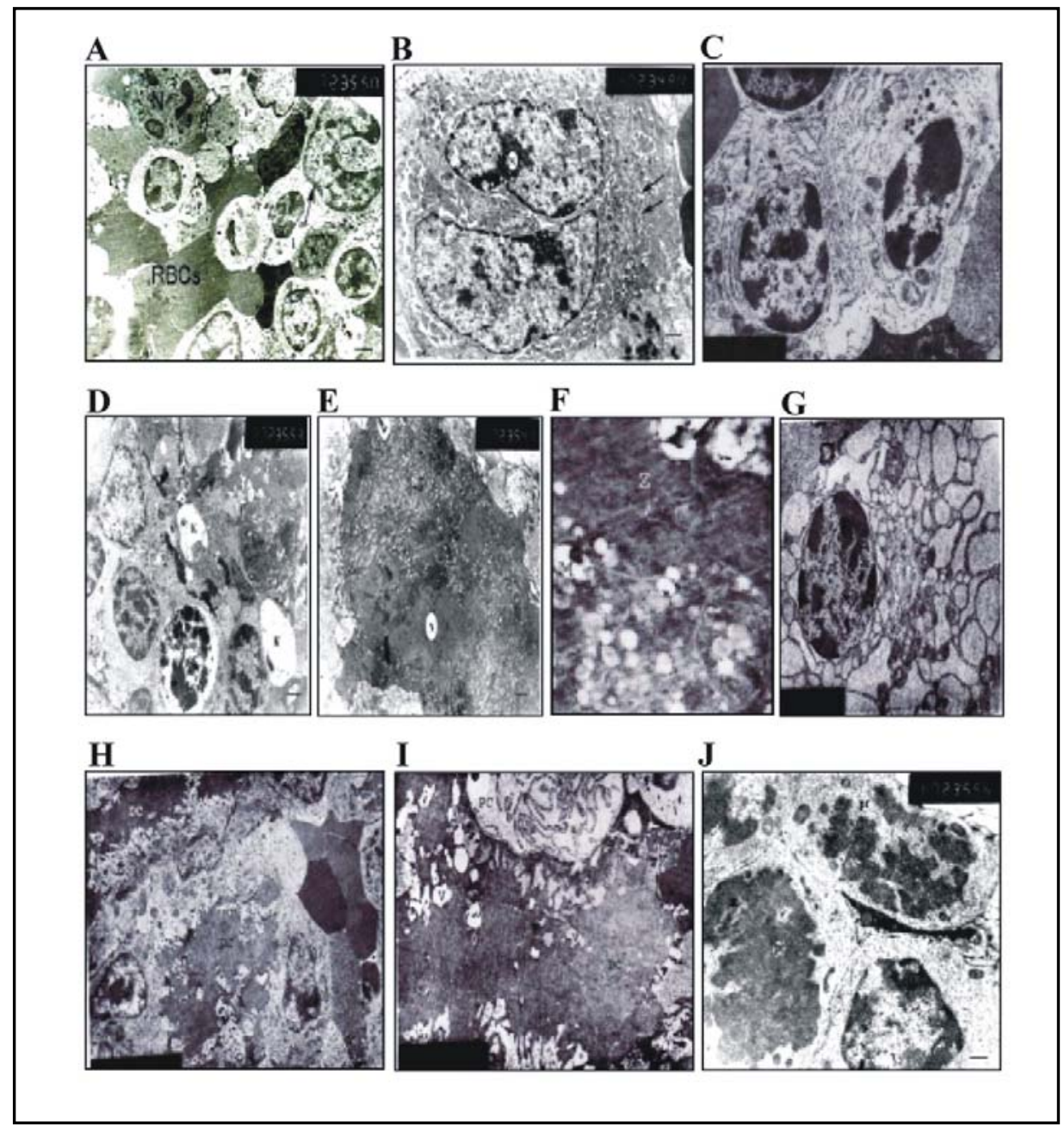

pulp in treated mice compared to control animals (Fig. 4 $\mathrm{G} \& \mathrm{H})$. HSCORE for the $\mathrm{B}$ and $\mathrm{T}$ cell immunostaining revealed a significant reduction in $\mathrm{B}$ cell homing the splenic white and red pulps and significant two folded increase in the splenic T cells of treated animals compared to control mice (Table 1).

Type I IFN is Required for Functional Lymphocytes
Ultrastructure examination using electron microscope of the splenic cells in control (Fig. 5 A, B\&C) and treated animal (Fig. 5 D-J) revealed altered architecture with apoptotic characteristic of the splenic cells in anit-IFNAR1- treated compared to control mice.

Cell Physiol Biochem 2010;26:1029-1040

1035 
Fig. 6. Histological examination showing reduced $T$ cell number in the Thymus of antiIFNAR1-treated mice. Sections were taken from control (A) and anti-IFNAR1-treated (B-C-D) mice. Representative histology sections (original magnification, $\times 400$ ) were analyzed by immunofluorescent staining (A-B) with anti- CD3. $\mathrm{CD}^{+} \mathrm{T}$ cells are seen in excess in both cortex and medulla of control mice (A). In antiIFNAR1-treated, marked reduction of $\mathrm{CD}^{+} \mathrm{T}$ cell number was observed either in the cortex or in the medulla (B); magnification, 400X. Numerous apoptotic cells that have halfmoon shapes, apoptotic epithelial reticular cell with electron lucent cytoplasm, mitochondrial pyknosis and nuclear fragmentation were observed by electron microscope in treated mice (C-D).

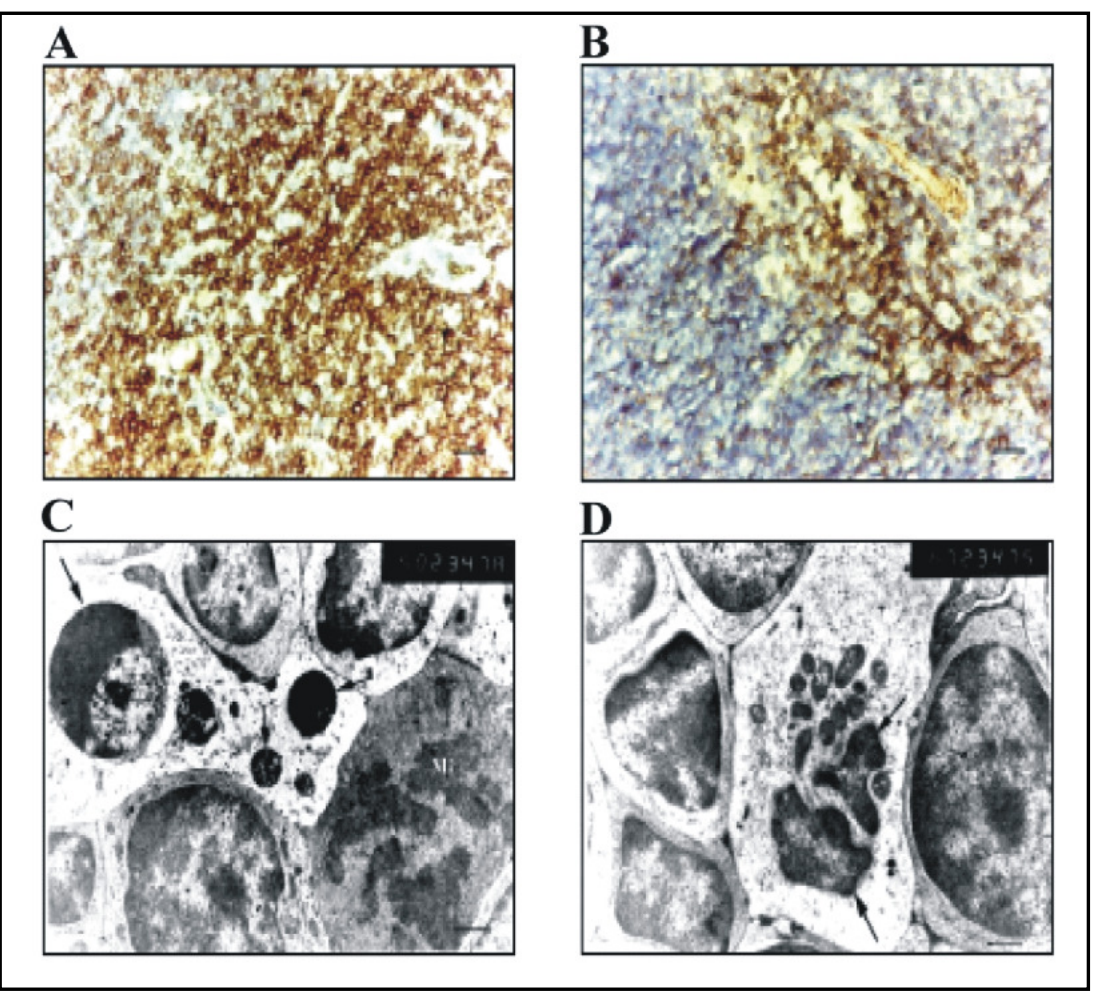

Thymic T cells. T cell development occurs in the thymus gland so to ensure whether $\mathrm{T}$ cell development was affected by the inhibition of type I IFN signaling, thymic tissue specimens of both control and anti-IFNAR1treated mice were stained by anti-CD3 antibody. CD3 ${ }^{+}$ $\mathrm{T}$ cells were distinguished with detectable colour in the thymus of control animals (Fig. $6 \mathrm{~A}$ ) and an obvious decrease in the thymus-resident $\mathrm{T}$ cells was observed in the treated animals (Fig. $6 \mathrm{~B}$ ). HSCORE for the T cell immunostaining revealed a significant reduction in the thymus-resident $\mathrm{T}$ cells of treated compared to control mice (Table 1). Ultrastructure examinations demonstrated in treated animals that numerous apoptotic cells were characterized by half-moon shapes, dense and homogenous electron density incorporated into stromal cells, electron lucent cytoplasm, mitochondrial pyknosis and nuclear fragmentation (Fig. 6 C\&D).

Peyer's patches-resident lymphocytes. Similar to what we found in the spleen, an enlargement of Peyer's patches in the most samples taken from treated mice was noticed in comparison to that of the control animals (Fig. 7 A). Likewise, CD20+ B cells were distinguished with detectable colour in the Peyer's patches tissue of control (Fig. 7. B) and an obvious decrease in B cells was observed in treated animals (Fig. 7 C). Otherwise, $\mathrm{CD}^{+} \mathrm{T}$ cells were markedly increased in the Peyer's patches tissue of anti-IFNAR1-treated mice compared to control animals (Fig.7 E\&D). HSCORE for both B and T cells immunostaining revealed a significant reduction in Peyer's patches-resident B cell number and significant increase in the $\mathrm{T}$ cell number of treated animals compared to control mice (Table 1). Furthermore, using electron microscope examination we observed in the treated mice numerous apoptotic cells with condensation of chromatin along the inner margin of nuclear envelope (Fig. $7 \mathrm{~F}$ ) and plasmacytoid dendritic cell exhibited apoptotic changes in the form of cell shrinkage and pyknotic nucleus with condensed chromatin and multiple cellular fragments (Fig. 7 G).

\section{Discussion}

Type I IFNs form a family of related cytokines that control a variety of cellular functions through binding to a receptor composed of IFNAR 1 and 2. IFNAR1 is the signaling chain, while IFNAR2 stabilize the binding of type I IFN with the receptor. Type I IFNs induce IFNR clustering and blocking of IFNAR1 but not IFNAR2 abrogate type I IFN signaling [22]. Among type I IFNs, the IFN $\alpha 2$ and IFN $\beta$ subtypes exhibit a large difference in their binding affinities to IFNAR1 [23]. Anti-IFNAR1 monoclonal antibodies (mAbs), generated from IFNAR $1^{-/-}$mice immunized by in vivo hydrodynamic transfection, block type I IFN receptor signaling and biologic response induction in vitro and in vivo [24].

Badr/Waly/Saad Eldien/Abdel-Tawab/Hassan/Alhazza/Ebaid/Alwasel 


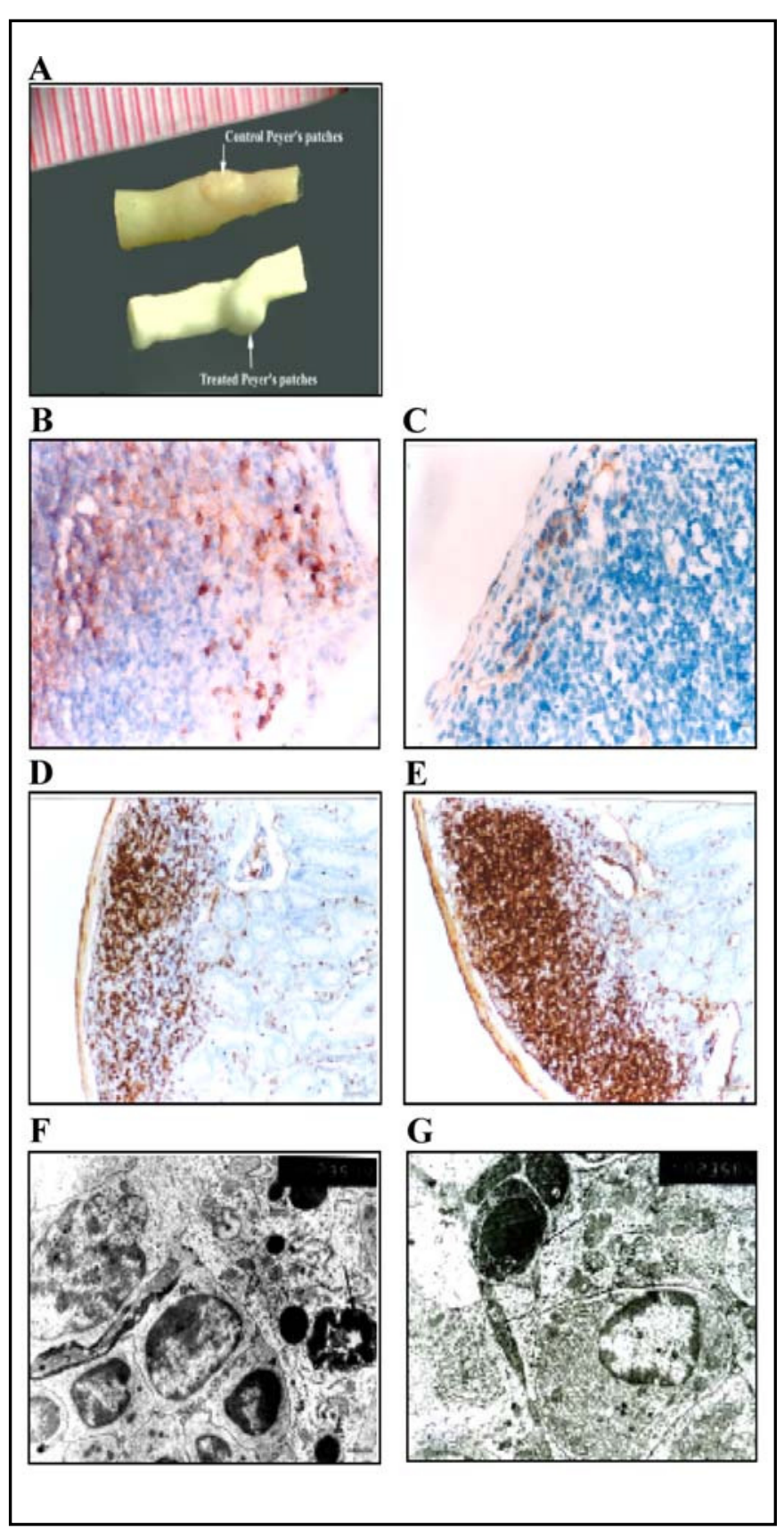

Fig. 7. Histological examination showing reduced $B$ cell number and increased infiltration of T cells in the PP of anti-IFNAR1treated mice. Enlargement in the PP was mostly observed in the majority of specimens taken from the anti-IFNAR1-treated mice (A). Sections were taken from control (B-D) and anti-IFNAR1treated (C-E-F-G) mice. Representative histology sections (original magnification, $\times 400$ ) were analyzed by immunofluorescent staining with anti-CD20 (B-C) showing reduced B cell number in the treated mice, otherwise sections that were stained with CD3 (D-E) demonstrating obvious increase in T cell number in the treated mice. Electron microscope examination of the PP from treated mice revealed numerous apoptotic cell with condensation of chromatin (F) and plasmacytoid dendritic cell exhibited apoptotic changes: cell shrinkage, pyknotic nucleus with condensed chromatin and multiple cellular fragments $(G)$.

Type I IFN is Required for Functional Lymphocytes
Based on our recent finding, IFN- $\alpha / \beta$ promote survival of human primary $\mathrm{B}$ cells via $\mathrm{PI} 3 \mathrm{~K} \delta / \mathrm{Akt}$, Rho-A, $\mathrm{NFKB}$ and $\mathrm{Bcl}-2 / \mathrm{Bcl}_{\mathrm{XL}}$ [16]. The effects of PI3Ks in numerous biological processes are including cell growth, differentiation, survival, proliferation, migration and metabolism [25]. These findings give us evidence that injection of anti-IFNAR $1 \mathrm{mAb}$ blocks PI3K signaling pathway through $\mathrm{B}$ and $\mathrm{T}$ lymphocytes.

Type I IFN is a pleiotropic cytokine, depending on the context, duration of exposure and disease state. However, results strongly provided clear evidences on the crucial role of the type I IFNs in differentiation, activation and maintaining mature normal functional lymphocytes. As analyzed by flow cytometery, the numbers of B lymphocytes, CD $4^{+}$helper T lymphocytes and $\mathrm{CD} 8^{+}$cytotoxic $\mathrm{T}$ lymphocytes were reduced in anti-IFNAR1-treated animals. Similarly, [26] using both IFNAR1- and IFNAR2-deficient mice, as well as an IFNAR1-blocking $\mathrm{Ab}$, demonstrated that endogenous type I IFN is critical for controlling NK cell-mediated antitumor responses in many experimental tumor models. It was found also that type I IFNs activate dendritic cells (DCs) and antigen-presenting cells (APC) for initiating immunity [27], by promoting the expression of costimulatory molecules $[28,29]$. Type I IFNs also have direct effects on $\mathrm{T}$ cells, particularly $\mathrm{CD} 8^{+} \mathrm{T}$ cells [30], by extending their survival during antigen-driven clonal expansion $[31,32]$. It inhibits the death of activated $\mathrm{CD}^{+} \mathrm{T}$ cells [33], a finding which was later extended to the adoptive transfer of antigen-specific $\mathrm{CD}^{+} \mathrm{T}$ cells lacking the expression of type I IFN receptors [34]. Indeed a marked reduction was observed in the cell recovery number stimulated with mitogen in anti-IFNAR-treated mice (data not shown). In control mice, the percentage of CFSE-labeled non-stimulated $\mathrm{CD} 45 \mathrm{R} / \mathrm{B} 220^{+} \mathrm{B}$ cells was increased in mitogen-stimulated B cells. While, blocking type I IFN signaling results in obvious reduction in the proliferation of $\mathrm{T}$ and $\mathrm{B}$ cells. B cells costimulated through their antigen receptor and cytokines such as IL-2, IL-4 and IL-10 undergo limited proliferation and differentiation into immunoglobulin secreting cells [35]. Results revealed that plasma levels of IL-2 and IL-7 were significantly reduced. In the absence of endogenous type I IFN, the cytokine immunotherapy was abrogated in IFNAR-deficient mice, primarily due to a defect in IL-2-induced cytotoxic activity [26]. The IL-2 levels are associated with number and percentage of the 'memory' $\left(\mathrm{CD} 4{ }^{+} / \mathrm{CD} 45 \mathrm{RO}^{+}\right)$ subset of $\mathrm{T}$ cells which mediates the host response to previously met antigens [36]. As the IL-2 values were 
significantly low in treated group, it was associated with a reduced memory compartment; this suggests a possible mechanism of why these mice can be more susceptible to morbidity and mortality from infections.

Marijanovic et al., [23] tested whether receptorproximal signaling events are sensitive to IFNAR1 surface concentration and found that the cell-surface IFNAR1 level is a limiting factor for assembly of the functional complex. An increased concentration of it does not translate into an IFN $\alpha / \beta$ differential JAK/STAT signaling nor does it change the dynamics of the engaged receptor. Normally, lymphocytes navigate from the periphery to the second lymphoid organs where they recognize the antigens. Defect in the homing of lymphocytes to the lymphoid tissues leads to defective immune response.

Our results revealed an increase of apoptosis in B cells of spleen and Peyer's patches and T cells of the thymus. Correspondingly, there was a reduction in the number of B cells in spleen and Peyer's patches and T cell numbers in the thymus. Decreased B and T cells in lymphoid organs have been hypothesized previously by the reduction of in vitro the migration (homing) of CD20positive B cells to the lymphoid tissues after treatment with anti-IFNAR1 $\mathrm{mAb}$ [24]. It has been proven that IFN $\alpha$ increased B cell chemotaxis to CXCL12, CXCL13, CCL20 and CCL21 and subsequently to lymphoid organs [37]. The constitutive production of IFN- $\alpha / \beta$ in primary lymphoid organs support the notion that they play an important role in B and T cell development [38]. Furthermore, IFN- $\alpha$ impaired T- and B-cell development at the pro- $\mathrm{T}$ and pro-B, IL-7-responsive, stages in the thymus and bone marrow, respectively [39].

It has been established that a class IA PI3K, p1108, is required for maximal $\mathrm{B}$ cell chemotaxis to CXCL13 and for B cell homing to Peyer's patches and to the splenic white pulp. Thus, it was found that analysis of lymphoid organs in $\mathrm{p} 110 \delta$-deficient mice revealed that B cell numbers were severely diminished in Peyer's patches as well as reduced B cell entry into the splenic white pulp. However, $\mathrm{T}$ cell migration to these organs were unaffected by $\mathrm{p} 110 \delta$ deficiency [40]. Therefore, in the present study, the observation of increased CD3-positive T cells in the spleen as well as in Peyer's patches might be explained by the differential roles for PI3K family members in B and $\mathrm{T}$ cell migration.

It is well known that high endothelial venules (HEVs) are specialized post-capillary venules found in lymphoid tissues that support high levels of lymphocyte extravasation from the blood. In spite of the absence of the HEV in the spleen, lymphocyte migration was reported to occur via marginal blood sinuses [41]. It is now clear that chemokines and no doubt other adhesion molecules are responsible for naive $\mathrm{T}$ - and $\mathrm{B}$-cell migration into the appropriate areas of the splenic sub architecture [42]. The observed enlargement in both spleen and Peyer's patches from treated mice with anti-IFNAR 1 was interpreted due to increased CD3-positive-cells in these organs. Light microscopic examination showed dilated congested marginal blood sinusoids in the spleen. This result is consistent with a recent study pointed out that tezosentan, a dual endothelin ETA/ETB receptor antagonist, caused venous sinusoidal dilation in the spleen [43].

The most frequent mitochondrial abnormalities observed in the present study were marked swelling with peripherally placed, disorientated, and disintegrated cristae. Study of mitochondrial morphology is important because changes in mitochondrial ultrastructure reflect any change that might occur in mitochondrial function [44] Mitochondrial swelling is always an osmotic process that results from net solute and water diffusion towards the matrix. Swelling of the matrix would be required to make more cytochrome $\mathrm{c}$ available for release into the cytosol [45]. In some mitochondria, it was also noted a reduction of their size with a hyper density of their matrix (mitochondrial pyknosis) as those observed in the thymus. Mitochondrial pyknosis as specific alternation of mitochondrial morphology correlated with mitochondrial dysfunction [46].

Ultrastructural studies of megakaryocytes in the present study showed results varying from moderate vacuolization, which might be due to dilatation in the rough endoplasmic reticulum (RER), collapsed mitochondrial cristae as well as marked dilatation of the demarcation membrane system. Because anti-platelet antibodies bind to antigens present on the surface of megakaryocytes [47], it is likely that this interaction plays an important role in initiating the cascade of programmed cell death.

The apoptotic changes that observed frequently in the lymphocytes might be explained on the basis of the deprivation of the interferon survival effect that exerted on these cells under normal circumstances. The ultrastructural alterations observed in the present study are compatible with the morphologic criteria for apoptosis and para-apoptosis. Para-apoptosis, first described by Asher et al. [48] is characterized by condensed chromatin and cytoplasmic vacuolization due to swollen mitochondria and endoplasmic reticulum. In contrast to necrosis, there is no cell membrane disruption. In these conditions, cells die as a result of caspase activation and mitochondrial

Badr/Waly/Saad Eldien/Abdel-Tawab/Hassan/Alhazza/Ebaid/Alwasel 
membrane permeabilization that constitute hallmarks of apoptosis [49].

These findings provide that the obvious reduction in the lymphocyte number in the peripheral blood and the lymphoid organs might be attributed mainly to first, the significantly reduction in plasma levels of IL-2 and IL-7 which, in normal, maintain mature normal functional lymphocytes; Second, the reduction of the migration (homing) of the lymphocytes to the lymphoid organs; Third, the anti-IFNAR1 mAb-induced apoptosis of these cells by impairing the type I IFNs pathways. Increased $\mathrm{T}$ cell number in the spleen and PP of treated mice may be due infiltration and abnormal exit of these cells from these special organs. Taken together, our data provide a protective role of type I IFNs $(\mathrm{IFN}-\alpha / \beta)$ on B and T- lymphocytes in vivo. Further detailed investigations in this subject have already started in our laboratory.

\section{Abbreviations}

AKT/PKB (Protein kinase B); Bcl-2 (B-cell Leukemia 2); IFN (Interferon); IFNAR1 (Interferon-alpha receptor1); NF- $\kappa \mathrm{B}$ (Nuclear factor- $\kappa \mathrm{B})$; PI3K (Phosphatidylinositol 3-kinase); Rho-A (Aplysia ras-related homolog A).

\section{Acknowledgements}

This research was supported by Faculty of Science, Assiut University, Egypt, and King Saud University, Saudi Arabia, through the Fetal Programming of Diseases Research Chair. We thank Dr. Emad Ahmed (Zoology department - Faculty of Science - Assiut University) for revising the manuscript and figures.

\section{References}

Kerr JFR, Wyllie AH, Currie AR: Apoptosis: a basic biological phenomenon with wide-ranging implications in tissue kinetics. $\mathrm{Br} \mathrm{J}$ Cancer 1972;26:239-257.

$>2$ Regan RF, Panter SS, Witz A, Tilly JL, Giffard RG: Ultrastructure of excitotoxic neuronal death in murine cortical culture. Brain Research 1995;705:188-198.

-3 Ihara T, Yamamoto T, Sugamata, M, $>8$ Okumura H, Ueno Y: The process of ultrastructural changes from nuclei to apoptotic body. Virchows Arch 1998;433:443-447.

-4 Seymour R, Sundberg JP, Hogenesch H: Abnormal lymphoid organ development $>9$ in immunodeficient mutant mice. Vet Pathol 2006;43:401-423.

$\checkmark 5$ Ehrchen JM, Roth J, Roebrock K, Varga G, Domschke W, Newberry R, Sorg C, Müller-Tidow C, Sunderkötter C, Kucharzik T, Spahn TW: The Absence of Cutaneous Lymph Nodes Results in a Th2 Response and Increased Susceptibility to Leishmania major Infection in Mice. Infect Immun 2008;76:42414250 .
Pabst O, Herbrand H, Bernhardt G, Förster $\mathrm{R}$ : Elucidating the functional anatomy of secondary lymphoid organs. Curr Opin Immunol 2004;16:394-399.

Li ZF, Zhang S, Lv GB, Huang Y, Zhang W, Ren S, Yang J, Dang SS: Changes in count and function of splenic lymphocytes from patients with portal hypertension. World J Gastroenterol 2008; 14:2377-2382.

Tsunoda I, Libbey JE, Kuang LQ, Terry EJ, Fujinami RS: Massive Apoptosis in Lymphoid Organs in Animal Models for Primary and Secondary Progressive Multiple Sclerosis. Am J Pathol 2005;167:1631-1646.

Oritani K, Kincade PW, Zhang C, Tomiyama Y, Matsuzawa Y: Type I interferon and limitin: a coparision of structures, receptors, and functions. Cytokine Growth Factor Rev 2001;12:337-348. Bach, EA, Aguet M, Schreiber RD: The IFN gamma receptor: a paradigm for cytokine receptor signaling. Annu Rev Immunol 1997;15:563-591.
Heim MH: The Jak-STAT pathway: cytokine signaling from the receptor to the nucleus. J Receptor Signal Transduc Res 1999;19:75-120.

Deonarain R, Chan DC, Platanias LC, Fish EN: Interferon-alpha-receptor interactions: A complex story unfolding. Curr Pharm Des 2002;8:2131-2137. Lamken P, Lata S, Gavutis M, Piehler J: Ligand-induced assembling of the type I interferon receptor on supported lipid bilayers. J Mol Biol 2004;341:303-318. Claudinon J, Gonnord P, Beslard E, Marchetti M, Mitchell K, Boularan C, Johannes L, Eid P, Lamaze C: Palmitoylation of interferon-alpha (IFNalpha) receptor subunit IFNAR1 is required for the activation of Stat 1 and Stat2 by IFN-alpha. J Biol Chem 2009;284:24328-24340.

15 Van den Broek MF, Mûller U, Huang S, Zinkernagel RM, Aguet M: Immune defense in mice lacking type I and/or type II interferon receptors. Immunol Rev 1995;148:5-18. 
$>16$ Badr G, Saad H, Waly H, Hassan K, Abdel- >28 Tawab H: Type I interferon (IFN-alpha/ beta) rescues B-lymphocytes from apoptosis via PI3Kdelta/Akt, Rho-A, NFkappaB and $\mathrm{Bcl}-2 / \mathrm{Bcl}(\mathrm{XL})$. Cellular $>29$ Immunol 2010;263:31-40

17 Kazi M, Thyberg J, Religa P, Roy J, Eriksson P, Hedin U, Swedenborg J: Influence of intraluminal thrombus on structural and cellular composition of abdominal aortic aneurysm wall. J Vasc Surg 2003;38:1283-1292.

18 Budwit-Novotny DA, McCarty KS, Cox EB, Soper JT, Mutch DG, Creasman WT: Immunohistochemical analyses of estrogen receptor in endometrial adenocarcinoma using a monoclonal antibody. Cancer Res 1986;46:5419-5425.

19 Murray MJ, Zhang J, Lessey BA: Expression of $\mathrm{a} 6$ and $\mathrm{b} 4$ integrin subunits throughout the menstrual cycle: no correlation with uterine receptivity. Fertil Steri 1999;72:522-526.

20 Gupta PD: Ultrastructural study on Semithin section. Science Tools 1983;30:6-7.

21 Drury R, Wallington EA: Carleton's histological techniques. 5th ed, Oxford University Press, 1980.

22 Nicole A, de Weerd SA, Samarajiwa, Paul JH: Type Interferon Receptors: Biochemistry and Biological Functions. J Biol Chem 2007;28:20053-20057.

23 Marijanovic Z, Ragimbeau J, van Heyden J, Uzé G, Pellegrini S: Comparable potency of IFNalpha2 and IFNbeta on immediate JAK/STAT activation but differential down-regulation of IFNAR2. Biochem J 2007;407:141-151.

$>24$ Sheehan KC, Lai KS, Dunn GP: Blocking monoclonal antibodies specific for mouse IFN-alpha/beta receptor subunit 1 (IFNAR-1) from mice immunized by in vivo hydrodynamic transfection. J Interferon Cytokine Res 2006;26:804-819.

25 Okkenhaug K, Vanhaesebroeck B: PI3K in lymphocyte development, differentiation and activation. Nat Rev Immuno 2003;3:317-330.

-26 Swann JB, Hayakawa Y, Zerafa N, Sheehan KC, Scott B, Schreiber RD, Hertzog P, Smyth MJ: Type I IFN contributes to NK cell homeostasis, activation, and antitumor function. J Immunol 2007; 178:7540-7549.

$>27$ Blanco P, Palucka AK, Gill M, Pascual V, Banchereau J: Induction of dendritic cell differentiation by IFN- $\alpha$ in systemic lupuerythematosus. Science 2001;294:1540-1543.
Gallucci S, Lolkema M, Matzinger P: Natural adjuvants: endogenous activators of dendritic cells. Nat Med 1999;5:12491255 .

Ito $\mathrm{T}$, Amakawa $\mathrm{R}$, Inaba $\mathrm{M}$, Ikehara $\mathrm{S}$, Inaba $\mathrm{K}$, Fukuhar $\mathrm{S}$ : Differential regulation of human blood dendritic cell subsets by IFNs. J Immunol 2001;166:29612969.

30 Tough DF, Borrow P, Sprent J: Induction of bystander $\mathrm{T}$ cell proliferation by viruses and type I interferon in vivo. Sci- 41 ence 1996;272:1947-1950.

-31 Kolumam GA, Thomas S, Thompson LJ, Sprent J, Murali-Krishna K: Type I interferons act directly on CD8 T cells to allow clonal expansion and memory formation in response to viral infection. J Exp Med 2005;202:637-650.

32 Le Bon A, Durand V, Kamphuis E, Thompson C, Bulfone-Paus S, Rossmann C, Kalinke U, Tough DF: Direct stimulation of $\mathrm{T}$ cells by type I IFN enhances the CD8+ T cell response during crosspriming. J Immunol 2006;176:46824689.

Marrack P, Kappler J, Mitchell T: Type $\mathrm{I}$ interferons keep activated $\mathrm{T}$ cells alive. J Exp Med 1999;189:521-530.

$>34$ Havenar-Daughton C, Kolumam GA, Murali-Krishna K: Cutting edge: the direct action of type I IFN on CD4 T cells is critical for sustaining clonal expansion in response to a viral but not a bacterial infection. $\mathrm{J}$ Immunol 2006;176:3315-3319.

-35 Banchereau J, Brière F, Liu YJ, Rousset F: Molecular control of B lymphocyte growth and differentiation. Stem Cells 1994; 12:278-288

36 Rea IM, Stewart M, Campbell P, Alexander HD, Crockard AD, Morris TC: Changes in lymphocyte subsets, interleukin 2, and soluble interleukin 2 receptor in old and very old age. Gerontology 1996;42:69-78.

37 Badr G, Borhis G, Treton D, Richard Y: IFN-alpha enhances human B-cell chemotaxis by modulating ligand-induced chemokine receptor signaling and internalization. Int Immunol 2005;17:459467.

$>38$ Wang J, Lin Q, Langston H, Cooper MD: Resident bone marrow macrophages produce type 1 interferons that can selectively inhibit interleukin-7-driven growth of B lineage cells. Immunit 1995;3:475484.
Lin Q, Dong C, Cooper MD: Impairment of $\mathrm{T}$ and $\mathrm{B}$ cell development by treatment with a type I interferon. J Exp Med 1998;187:79-87.

Reif K, Okkenhaug K, Sasaki T, Penninger JM, Vanhaesebroeck B, Cyster JG: Cutting edge: differential roles for phosphoinositide 3-kinases, p110gamma and p110delta, in lymphocyte chemotaxis and homing. J Immunol 2004; 173:2236-2240.

Girard JP, Springer TA: High endothelial venules (HEVs): specialized endothelium for lymphocyte migration. Immunol 1995;16:449-457.

$>42$ Forster R, Schubel A, Breitfeld D: CCR7 coordinates the primary immune response by establishing functional microenvironments in secondary lymphoid organs. Cell 1999;99:23-33.

Erdem A, Sevgili AM, Akbiyik F: Tezosentan attenuates organ injury and mesenteric blood flow decrease in endotoxemia and cecal ligation and puncture. J Surg Res 2007;141:211-219.

$\checkmark 44$ Sastre J, Pallardo FV, Vina J: Mitochondrial oxidative stress plays a key role in aging and apoptosis. Life 2000;49:427435 .

Bernardi P, Scorrano L, Colonna R, Petronilli V, Lisa FD: Mitochondria and cell death. Eur J Biochem 1999;264:687701.

Brajuskovic GR., Skaro-Milic AB, Marjanovic SA, Cerovic SJ, KnezevicUsaj SF: The ultrastructural investigation of mitochondria in B-CLL cells during apoptosis. Arch Oncol 2004;12:139-141. Houwerzijl EJ, Blom NR, Want JJd, Esselink MT, Koornstra JJ, Smit JW, Louwes H, Vellenga E, de Wolf JT: Ultrastructural study shows morphologic features of apoptosis and para-apoptosis in megakaryocytes from patients with idiopathic thrombocytopenic purpura. Blood 2004;103:500-506.

Asher E, Payne CM, Bernstein C: Evaluation of cell death in EBV-transformed lymphocytes using agarose gel electrophoresis, light microscopy and electron microscopy. II. Induction of non-classic apoptosis ("para-apoptosis") by tritiated thymidine. Leuk Lymphoma 1995;19:107-119

49 Vakifahmetoglu $\mathrm{H}$, Olsson $\mathrm{M}$, Zhivotovsky B: Death through a tragedy: mitotic catastroph. Cell Death Differ 2008;15:1153-1162. 


\section{Cellular Physiology and Biochemistry

Several errors occurred in the article by G. Badr, H. Waly, H.M. Saad Eldien, H. Abdel-Tawab, K. Hassan, I.M. Alhazza, H. Ebaid, and S.H. Alwasel, entitled 'Blocking Type I Interferon (IFN) Signaling Impairs Antigen Responsiveness of Circulating Lymphocytes and Alters Their Homing to Lymphoid Organs: Protective Role of Type I IFN' [Cell Physiol Biochem 2010;26:1029-1040 (DOI:10.1159/000323978)].

There is a mistype error in the name of antibody 'CD220'. It should read 'B220':

- Page 1029: Abstract, Line 12: 'Results: Flow cytometry analysis to monitor the blood lymphocyte phenotype and proliferation have shown a significant decrease in CD45R/CD220+ B cells, CD4+ and CD8+ $T$ cells in treated animals' is incorrect.

It should read: 'Results: Flow cytometry analysis to monitor the blood lymphocyte phenotype and proliferation have shown a significant decrease in CD45R/B220+ B cells, CD4+ and CD8+ T cells in treated animals'.

- Page 1031: CFSE-Labeled Cell Proliferation Assay: Line 16: 'On day 6, cells were washed in PBS and were stained with surface antigens anti-CD3-PE, CD45A/CD220-PE [RA3-6B2 and rat IgG2a, $\kappa$ ] or isotype control (BD biosciences)' is incorrect.

It should read: 'On day 6, cells were washed in PBS and were stained with surface antigens anti-CD3-PE, CD45A/B220-PE [RA3-6B2 and rat IgG2a, $\mathrm{k}$ ] or isotype control (BD biosciences)'.

- In Figure 1, panel A: 'CD45R/CD220-FITC' is incorrect. It should read: 'CD45R/B220-FITC'.

The authors regret any inconvenience caused. 